\title{
P255: Study on the prevalence of healthcare associated infections in hospitals of Niger
}

\author{
G Bawa-Alla ${ }^{1 *}, \mathrm{H}_{\mathrm{Djibo}}^{2}$ \\ From 2nd International Conference on Prevention and Infection Control (ICPIC 2013) \\ Geneva, Switzerland. 25-28 June 2013
}

\section{Introduction}

This study on the prevalence of nosocomial infection in long ignored Niger took place in three (3) national hospitals (HNN HNL and MIG) and two (2) regional reference centres (Maradi and Diffa). These institutions were selected on the basis of use of services and technical platforms.

\section{Objectives}

To evaluate the prevalence of nosocomial infections in hospitals in Niger.

\section{Methods}

A point prevalence survey making an assessment on "any given day" in each of the participating services, whose main characteristics were: Five hospitals totaling 1506 beds were concerned; 1040 hospitalized patients of whom 524 were male and 516 female bed occupancy $69.05 \%, 68$ samples with microbial susceptibility testing were performed.

\section{Results}

Clinical Results

a prevalence of $7.3 \%$ of infected patients (76 patients) and $7.78 \%$ of nosocomial infections identified a ratio of infections / infected of $1.05,93.42 \%$ of nosocomial infections are acquired in institutions; specialties most affected are general surgery (26\%), gynecology and obstetrics $(20 \%)$, general medicine $(9.2 \%)$ and gastrointestinal surgery and pediatrics (7.9\%).

\section{Microbiological Results}

68 samples coming from the gynecology obstetrics services, general surgery, general medicine and Pediatrics, 51 samples out of 69 have at least one nosocomial strain (positive), $86 \%$ of the pus, urine and $71.42 \% 100 \%$ positive catheters; 70 pathogens consisting of 10 identified species, the four most commonlz isolated were: Staphylococcus aureus (41.41\%), Pseudomonas (15.71\%), Klebsiella (11.42\%) and Eschericha coli (10\%) species are most involved.

\section{Conclusion}

This study has allowed us to make an inventory of the quality of care in hospitals and to expose the problem of nosocomial infections long ignored Care in Niger.

\section{Competing interests}

None declared.

\section{Author details}

${ }^{1}$ Focal quality of care, Department of Public Health, Niger. ${ }^{2}$ Department of Public Health, Faculty of Health Sciences, University of Niamey, Niamey, Niger.

Published: 20 June 2013

\section{doi:10.1186/2047-2994-2-S1-P255}

Cite this article as: Bawa-Alla and Djibo: P255: Study on the prevalence of healthcare associated infections in hospitals of Niger. Antimicrobial Resistance and Infection Control 2013 2(Suppl 1):P255.

${ }^{1}$ Focal quality of care, Department of Public Health, Niger

Full list of author information is available at the end of the article

(c) 2013 Bawa-Alla and Djibo; licensee BioMed Central Ltd. This is an Open Access article distributed under the terms of the Creative 